\title{
Recent achievements in the field of research of pathogens and methods of treatment and prevention of Mortellaro Disease
}

\author{
Natalya Belyakova ${ }^{1 *}$, Anatolyi Kovalenko ${ }^{1}$, Yuliya Bodrova ${ }^{1}$, and Viktoriya Oskolskaya ${ }^{1}$ \\ ${ }^{1}$ Department of Infectious and Invasive Pathology Belgorod State Agricultural Academy, vil.. Mayskiy, Russia
}

\begin{abstract}
In the course of research on the search for substances active in the fight against Mortellaro's disease, a drug for the treatment and prevention of skin and skin diseases was developed and tested on the basis of zinc and copper metals immersed in the niosomal structures with the addition of Dimethicone copolyol. These components were selected as proven antiseptic. The therapeutic effect was compared at different concentrations of metals in the drug. Practical experiments have shown a high therapeutic effectiveness of the received drug for the treatment of skin and skin diseases of animals, including Mortellaro disease.
\end{abstract}

\section{Introduction}

Mortellaro disease is an infectious disease of the hooves of cattle, affecting mainly the hind limbs, transmitted through the environment, the causative agents of the disease is a combination of bacteria. [1] The classification of lesions, by which the severity of the process of Mortellaro disease is standardly determined, was developed by Döpfer and expanded by Berry [2]. Classification describes six stages of the disease: M0animal healthy, M1-active granulomatous area $0-2 \mathrm{~cm}$, M2-ulcerative lesion with an area of more than $2 \mathrm{~cm}, \mathrm{M} 3-$ ulcerative lesion covered with a scab, M4-skin change with signs of Mortellaro disease and M4. 1-recurrent lesion. [3]

Over the past decade, studies of pathogens of Mortellaro disease have revealed a wide range of organisms - potential agents of disease development. Researchers in most countries have concluded that the predominant morphotypes detected from active lesions of the disease and the main pathogens of Mortellaro disease are treponemes, which differ in phylogenetic and serological characteristics [4-11]. The Resulting Treponema species are defined in three groups: Treponema medium / Treponema vincentii-like, Treponema phagedenis-like, and Treponema denticola/Treponema putidum-like, the latter now classified as a new species, Treponema pedis [12].

The pathogenesis of the disease is associated with the penetration of Treponema into the skin of the hoof after damage to the epidermis and keratin layer. Loss of the keratin layer is the primary sign of the development of Mortellaro disease. It is assumed that Treponema pathogens secrete keratolytic toxin at an early stage of the disease [13]. This is accompanied by hyperplasia and hypertrophy of the epithelium to more than 100 cells per
$1 \mathrm{~mm}$, with a normal thickness of $5-70$ cells (Blowey et al., 1994; Döpferet al., 1997). [14] Dichelobacter nodusus bacteria, secreting proteolytic enzymes, destroy successively the surface and Central layers of the epidermis, after which spirochetes of the PT1, PT3, PT6, PT8 and Treponema brennaborense phylotypes that live in the deep layers of the epidermis penetrate the unprotected skin $[15,16]$. Treponema spp. it can undergo morphological changes from helical to cysteated forms [17] The Transition to the form of cysts occurs inside the host as a manifestation of the protective mechanism and one of the ways of transmitting the infectious agent in the external environment [18]. The transition requires a temperature of $37^{\circ} \mathrm{Celsius}$ and an anaerobic environment, which is quite achieved in the deep layers of the hoof skin.

Based on the data obtained from the study of 12 farms in the Netherlands, scientists I. Demirkan, M. Erdoğan et al. we calculated the reproduction index of Mortellaro disease, which was 2.36. The active stages of the disease were considered Infectious. The transition from the M0 stage in $94 \%$ occurs in the M4 stage and the greatest part of the time the disease on farms occurred in the M4 stage, determining $88.5 \%$ R0. As dictated by scientists, preventing damage to the M4 would reduce R0 to unity and below. Treatment on farms occurs mainly in the active stages of the disease - M2 and M3, when there is a distinct lameness of the animal. [2] The M4 stage does not respond well to standard prevention in the form of hoof baths and antibiotic therapy due to the deep occurrence of cysts in the layers of the skin and subcutaneous tissue of the animal's hoof [19-21] but it is the elimination of this stage that will lead to a complete recovery of the herd. Therefore, further research on effective prevention and treatment of class M4 is crucial.

Medicine of the last decade has been actively searching for controlled carriers for the targeted delivery

* Corresponding author: belyakovanatalya2018@gmail.com 
of medical components to the site of the disease focus. They improve the therapeutic effectiveness of drug molecules by slowing clearance from circulation, protecting the drug from the biological environment and limiting the impact on target cells. This research is taking place in the field of nanotechnology. The most accessible nanocapsules to create and use are liposomal forms. However, the stability of these substances is relative, due to their organic origin. Their analogues-synthetic niosomes, in terms of bioavailability and protective properties, are not inferior to and in many respects surpass their predecessors. Niosomes are composed of lipid bilayer of non-ionic surfactant, optionally containing cholesterol and its derivatives. The size of these vesicles is from 50 to $800 \mathrm{~nm}$. They have the ability to overcome all the immune barriers of the body, including transdermal, and penetrate the necessary organs and tissues. For the treatment of infectious diseases of the skin and skin, which include Mortellaro disease, for many years, with high therapeutic indicators, copper and zinc metal salts are used, which have bactericidal properties and are able to inactivate the pathogens of Mortellaro disease, violating the membrane structures of the microorganism. To achieve higher treatment rates, the metal must be delivered to the pathogenic organism by enclosing it in a niosomal capsule. Based on this principle, we have developed a drug for the treatment of infectious diseases of the skin and skin of the distal extremities (Mortellaro disease) based on niosomes of copper and zinc salts. During the development of a suitable composition, a clinical trial of five samples of the drug with different ratios of niosomes of metal salts was conducted. The results are recorded and analyzed.

\section{Experimental}

\section{Materials and methods.}

The work was performed based on the Department of infectious and invasive pathology, laboratory of infectious and invasive pathologies and testing of veterinary drugs of the Belgorod state agrarian University named after V. ya. Gorin.

Scientific and production experiments were conducted based on the livestock farm of LLC "Green valley" of the Belgorod region.

The study of the features of clinical manifestations of skin and skin lesions of the distal extremities in Mortellaro disease was carried out directly in the conditions of a dysfunctional farm for diseases of the distal extremities of cattle. Clinical assessment of the intensity of lesions in Mortellaro disease was carried out according to the classification proposed by Döpfer, both before the beginning of research and during the course of therapeutic measures. Statistical processing of the obtained results was performed using the student's coefficient.

Development of a drug for the treatment of diseases of the distal extremities using niosomal forms of zinc oxide and copper sulfate and available ointment base.

On the basis of the laboratory of our university, several experimental samples of the product were created, consisting of an ointment base and niosomal forms of copper sulfate and zinc oxide distributed in its volume in concentrations from 0.2 to $2 \%$ of metals in solution, the surface of which was specially modified to ensure high efficiency on the skin and keratinized tissues. The size of niosomes reaches 30-80 nanometers. Niosomes are constructed from a shell in the form of a water-insoluble double layer of non-ionic emulsifier (surfactant), which belong to the group of dimethiconopolyols, which are ethers of polyethylene glycol and polydimethylsiloxane base and are enclosed within the capsule of the active substance. Transdermal transport of zinc oxide and copper sulfate occurs due to the ability of a non-ionic surfactant to form a double molecular layer, similar to the plasma membrane of a living cell. The presence of a si-O-Si covalent bond in the hydrophobic part of the polydimethylsiloxane base of the emulsifier, which has a high elasticity and reactivity, allows delivering a wide range of active substances using reactive sites and purposefully releasing them from the nanovesicle. Thus, Dimethicone copolyol represent hybrid silicon (Dimethicone) and carbon (polyethylene glycol).

$$
\text { Sample } 1
$$

\begin{tabular}{|c|c|}
\hline 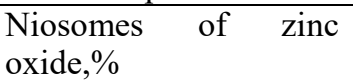 & $\begin{array}{l}\text { Niosomes of copper sulfate, } \\
\%\end{array}$ \\
\hline 0,1 & 0,1 \\
\hline \multicolumn{2}{|l|}{ Sample 2} \\
\hline $\begin{array}{l}\begin{array}{l}\text { Niosomes } \\
\text { oxide, } \%\end{array} \\
\text { of }\end{array}$ & $\begin{array}{l}\text { Niosomes of copper sulfate, } \\
\%\end{array}$ \\
\hline 0,15 & 0,1 \\
\hline \multicolumn{2}{|l|}{ Sample 3} \\
\hline 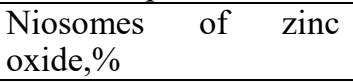 & $\begin{array}{l}\text { Niosomes of copper sulfate, } \\
\%\end{array}$ \\
\hline 0,15 & 0,15 \\
\hline \multicolumn{2}{|l|}{ Sample 4} \\
\hline 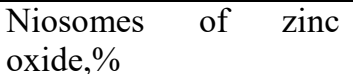 & $\begin{array}{l}\text { Niosomes of copper sulfate, } \\
\%\end{array}$ \\
\hline 0,2 & 0,2 \\
\hline \multicolumn{2}{|l|}{ Sample 5} \\
\hline $\begin{array}{lll}\begin{array}{l}\text { Niosomes } \\
\text { oxide, } \%\end{array} & \text { of } & \text { zinc } \\
\end{array}$ & $\begin{array}{l}\text { Niosomes of copper sulfate, } \\
\%\end{array}$ \\
\hline 0,8 & 0,5 \\
\hline
\end{tabular}

Conducting control tests to study the effectiveness of the drug on sick animals.

With each experimental sample of the drug, clinical studies were conducted for various forms of the Depfer pathological process, starting from M1, ending with M4, while taking into account the physiological lactation period in each group of cows and the size of the lesion dimension.

Analyzing the data in table 1, it should be noted that sample \#1 caused an active granulation process in animals with small M1 lesions with a red or white-red surface and possible exudation as early as 6 days after the start of treatment. The process was accompanied by enlightenment of the affected area and the appearance of pale pink epithelium.

Sample \# 2, used for treatment in the second group of animals, which contained 12 heads, allowed achieving the same result for 11 animals already on day 5 .

As for samples 3-5, the same regeneration processes were observed in all tested groups of animals in the 
corresponding number of animals, which was on average $96 \%$ effective.

Analyzing the data in table 2 , we note that cows 2 lactation respond to treatment of M1 lesions to a slightly lower degree. In group 1, the percentage of recovered animals was $95 \%$, in group $2-94 \%$, and among group 3, the percentage of recovered animals was also $89 \%$. Sample \#4 showed $94 \%$ effectiveness, and among 5 groups, recovered was $100 \%$. As the concentration of the drug increased, the response to treatment occurred on day 6 and on day 3 , respectively.

According to table 3 , the overall effectiveness of treatment was as high as in cows of the second lactation; however, based on the results of treatment indicators by day, it is clear that the therapeutic effect was achieved at a later date. For samples 1-3 - on the 6th day of treatment. The appearance of healing processes for samples 4 and 5 occurred already on the 3rd day, which indicates their higher therapeutic effectiveness.

Table 1. Cows of the first lactation with the development of a pathological process corresponding to M1 lesions according to the dopfer classification.

\begin{tabular}{|c|c|c|c|c|c|c|c|c|c|c|}
\hline \multirow[t]{2}{*}{ Sample number } & \multirow[t]{2}{*}{$\begin{array}{c}\text { Group of } \\
\text { animals (n) }\end{array}$} & \multicolumn{7}{|c|}{ Treatment by day (from 1 to 7 days) } & \multirow[t]{2}{*}{$\begin{array}{l}\text { Number of } \\
\text { recovered }\end{array}$} & \multirow[t]{2}{*}{$\begin{array}{l}\text { Percentage of } \\
\text { recovered }\end{array}$} \\
\hline & & 1 & 2 & 3 & 4 & 5 & 6 & 7 & & \\
\hline 1 & 14 & & & & & & + & & 13 & $93 \%$ \\
\hline 2 & 12 & & & & & + & & & 11 & $92 \%$ \\
\hline 3 & 17 & & & & + & & & & 16 & $94 \%$ \\
\hline 4 & 18 & & & + & & & & & 18 & $100 \%$ \\
\hline 5 & 14 & & & + & & & & & 14 & $100 \%$ \\
\hline Subtotal & & & & 75 & & & & & 72 & $96 \%$ \\
\hline
\end{tabular}

Table 2. Cows of the second lactation with the development of a pathological process, corresponding to M1 lesions according to the dopfer classification.

\begin{tabular}{|c|c|c|c|c|c|c|c|c|c|c|}
\hline Sample number & Group of animals (n) & \multicolumn{7}{|c|}{ Treatment by day (from 1 to 7 days) } & Number of recovered & Percentage of recovered \\
\hline & & 1 & 2 & 3 & 4 & 5 & 6 & 7 & & \\
\hline 1 & 21 & & & & & & + & & 20 & $95 \%$ \\
\hline 2 & 18 & & & & & + & & & 17 & $94 \%$ \\
\hline 3 & 18 & & & & + & & & & 16 & $89 \%$ \\
\hline 4 & 18 & & & + & & & & & 17 & $94 \%$ \\
\hline 5 & 17 & & & + & & & & & 17 & $100 \%$ \\
\hline Subtotal & & & 92 & & & & & & 87 & $95 \%$ \\
\hline
\end{tabular}

Table 3. Cows of the third lactation with the development of a pathological process corresponding to M1 lesions according to the dopfer classification.

\begin{tabular}{|c|c|c|c|c|c|c|c|c|c|c|}
\hline Sample number & Group of animals (n) & \multicolumn{7}{|c|}{ Treatment by day (from 1 to 7 days) } & Number of recovered & Percentage of recovered \\
\hline & & 1 & 2 & 3 & 4 & 5 & 6 & 7 & & \\
\hline 1 & 19 & & & & & & + & & 18 & $95 \%$ \\
\hline 2 & 15 & & & & & + & & & 14 & $93 \%$ \\
\hline 3 & 10 & & & & & & + & & 10 & $100 \%$ \\
\hline 4 & 12 & & & + & & & & & 12 & $100 \%$ \\
\hline 5 & 16 & & & + & & & & & 15 & $94 \%$ \\
\hline Subtotal & & & 72 & & & & & & 69 & $96 \%$ \\
\hline
\end{tabular}

Table 4. Cows of the fourth lactation with the development of a pathological process corresponding to M1 lesions according to the dopfer classification.

\begin{tabular}{|c|c|c|c|c|c|c|c|c|c|c|}
\hline \multirow[t]{2}{*}{ Sample number } & \multirow{2}{*}{$\begin{array}{c}\text { Group of } \\
\text { animals (n) }\end{array}$} & \multicolumn{7}{|c|}{ Treatment by day (from 1 to 7 days) } & \multirow{2}{*}{$\begin{array}{c}\text { Number of } \\
\text { recovered }\end{array}$} & \multirow{2}{*}{$\begin{array}{c}\text { Percentage of } \\
\text { recovered }\end{array}$} \\
\hline & & 1 & 2 & 3 & 4 & 5 & 6 & 7 & & \\
\hline 1 & 17 & & & & & & & + & 15 & $88 \%$ \\
\hline 2 & 17 & & & & & & & + & 16 & $94 \%$ \\
\hline 3 & 18 & & & & & & + & & 17 & $94 \%$ \\
\hline 4 & 10 & & & + & & & & & 10 & $100 \%$ \\
\hline 5 & 12 & & & + & & & & & 12 & $100 \%$ \\
\hline Subtotal & & & & 74 & & & & & 70 & $94 \%$ \\
\hline
\end{tabular}


Table 5. Cows of the fifth lactation with the development of a pathological process corresponding to M1 lesions according to the dopfer classification.

\begin{tabular}{|c|c|c|c|c|c|c|c|c|c|c|}
\hline Sample number & Group of & \multicolumn{7}{|c|}{ Treatment by day (from 1 to 7 days) } & \multirow{2}{*}{$\begin{array}{l}\text { Number of } \\
\text { recovered }\end{array}$} & \multirow{2}{*}{$\begin{array}{l}\text { Percentage of } \\
\text { recovered }\end{array}$} \\
\hline & & 1 & 2 & 3 & 4 & 5 & 6 & 7 & & \\
\hline 1 & 8 & & & & & & & + & 8 & $100 \%$ \\
\hline 2 & 11 & & & & & & & + & 10 & $91 \%$ \\
\hline 3 & 10 & & & & & & & + & 8 & $80 \%$ \\
\hline 4 & 8 & & & + & & & & & 8 & $100 \%$ \\
\hline 5 & 13 & & & + & & & & & 12 & $92 \%$ \\
\hline Subtotal & & & & 50 & & & & & 46 & $92 \%$ \\
\hline
\end{tabular}

Cows of the first lactation with M2 lesions, called "classic ulcers", which looked like red or white-red surfaces with a diameter of more than $1 \mathrm{~cm}$ with granulation or proliferative tissue (in large quantities or filamentously) and are average in severity of the process, respond to treatment fairly quickly relative to the severity of the process (table 6).

Even the minimum concentration of the drug gives a positive therapeutic effect for 6 days after the start of treatment. Optimal rates of response to treatment are also shown in samples 4 and 5. Moreover, in this case, sample 4 showed a greater percentage of efficiency than sample 5 . Due to the large variation in the effectiveness of images 1-3 and 4-5, the overall effectiveness of treatment was quite low.

Analysis of the table 7 showed that cows of the second lactation with hoof lesions characteristic of M2 according to the Depfer classification could be treated similarly to cows of the first lactation. The percentage of recovered animals in the groups increases relative to the increase in concentration of samples of the drug from \# 1 to \#4 and does not significantly change for the sample \#5 with the highest concentration. However, the overall effectiveness of treatment of second-lactation cows has reached $90 \%$.

According to the results of the table 8 , the average effectiveness of treatment of groups of animals during the third lactation reached $89 \%$. At the same time, the rate of response to treatment decreased, and for samples \# 1-3, the initial stage of proliferation and attenuation of inflammation occurred on the 7th day of treatment. Samples with the maximum concentration also showed a high rate of occurrence of the therapeutic effect: on the 4 th and 3rd days, respectively.

For cows of the fourth lactation, the timing of the response to treatment has shifted even more compared to animals of the first, second and third lactation. Tightening of the borders of lesions, lightening of inflammation occurred by the end of the first week after the use of the drug. Sample \# 4 showed 100\% therapeutic effectiveness, but the treatment period also shifted to the end of the week. The overall percentage of recovered cows after fourth lactation fell to $86 \%$, from which it can be concluded that cows respond to treatment worse with age (table 9).

The total number of cows of the fifth lactation in the farm is less than other lactations (table 10). The effectiveness of treatment of such cows is apparently lower than that of previous lactation cows. This confirms the correlation between age and treatment duration. Samples 4 and 5 with the maximum concentration of active substances in the composition showed $90 \%$ effectiveness of treatment with the appearance of visible regenerative manifestations on the 6 th and 5 th days of treatment, respectively. The percentage of effectiveness of samples \# 1-3 was quite low for the treatment of Mortellaro disease of the second M2 stage of the course and did not exceed $73 \%$.

Lesions of the hooves of cows with the First stage of Mortellaro disease are characterized by an acute form of flow, the presence of black necrotic scabs of tissue, and bleeding. This stage is considered as the most severe course of the process of Mortellaro disease.

Nevertheless, the therapeutic effectiveness of samples of the drug \# 4 and \# 5 reached 94 and 100\%, respectively. Signs of recovery in cows were observed on day 6 for two samples. The efficiency of samples No. 1-3 were also high, ranging from 75 to $80 \%$. The timing of the appearance of signs fell on the 7 th day(table 11).

Analysis of the table 12 data showed that the developed tool copes with severe skin lesions in Mortellaro disease with an efficiency of $91 \%$ with the most concentrated sample and $87 \%$ with the use of sample \#4 in sick cows of the second lactation. When testing sample \# 1 with minimal concentration, recovery processes began to appear only in the second week after the start of treatment. Therefore, for the treatment of severe Mortellaro disease, this sample is not suitable due to the duration of the process. Samples \# 2 and \#3 showed sufficient efficiency: 81 and $85 \%$, respectively.

According to the table 13, treatment of cows of the third lactation with the disease of Mortellaro stage M3 "acute", showed a high therapeutic effectiveness of the drug in General: $85 \%$ of the number of patients. The best performance indicators were achieved with the use of samples \#4 and \#5 - both showed 94\% therapeutic effectiveness at the same time of recovery (on the 6th day). This shows that the concentration of sample \#4 is sufficient for the treatment of severe stages of the disease among cows of the third lactation.

The effectiveness of samples \#4 and \#5 in the treatment of cows of the fourth lactation with the First stage of the disease was 92 and 93\%, respectively (table 14). These indicators are slightly lower than in the treatment of cows with severe lesions of the third lactation. 
Table 6. Cows of the first lactation with the development of a pathological process corresponding to M2 lesions according to the dopfer classification.

\begin{tabular}{|c|c|c|c|c|c|c|c|c|c|c|}
\hline Sample number & Group of & \multicolumn{7}{|c|}{ Treatment by day (from 1 to 7 days) } & \multirow{2}{*}{$\begin{array}{l}\text { Number of } \\
\text { recovered }\end{array}$} & \multirow{2}{*}{$\begin{array}{l}\text { Percentage of } \\
\text { recovered }\end{array}$} \\
\hline & & 1 & 2 & 3 & 4 & 5 & 6 & 7 & & \\
\hline 1 & 23 & & & & & & + & & 19 & $83 \%$ \\
\hline 2 & 24 & & & & & & + & & 21 & $87 \%$ \\
\hline 3 & 15 & & & & & & + & & 13 & $87 \%$ \\
\hline 4 & 18 & & & + & & & & & 17 & $94 \%$ \\
\hline 5 & 22 & & & + & & & & & 20 & $91 \%$ \\
\hline Subtotal & & & & 02 & & & & & 90 & $88 \%$ \\
\hline
\end{tabular}

Table 7. Cows of the second lactation with the development of a pathological process corresponding to M2 lesions according to the dopfer classification.

\begin{tabular}{|c|c|c|c|c|c|c|c|c|c|}
\hline $\begin{array}{c}\text { Group of animals } \\
\text { (n) }\end{array}$ & \multicolumn{7}{|c|}{ Treatment by day (from 1 to 7 days) } & $\begin{array}{c}\text { Number of } \\
\text { recovered }\end{array}$ & Percentage of recovered \\
\hline & $\mathbf{1}$ & $\mathbf{2}$ & $\mathbf{3}$ & $\mathbf{4}$ & $\mathbf{5}$ & $\mathbf{6}$ & $\mathbf{7}$ & & 18 \\
\hline 22 & & & & & & + & & 19 & $81 \%$ \\
\hline 21 & & & & & & + & & 14 & $93 \%$ \\
\hline 15 & & & & & + & & & 16 & $94 \%$ \\
\hline 17 & & & + & & & & & 18 & $95 \%$ \\
\hline 19 & & & + & & & & & $\mathbf{8 5}$ & $\mathbf{9 0 \%}$ \\
\hline
\end{tabular}

Table 8. Cows of the third lactation with the development of a pathological process corresponding to M2 lesions according to the dopfer classification.

\begin{tabular}{|c|c|c|c|c|c|c|c|c|c|c|}
\hline Sample number & Group of & \multicolumn{7}{|c|}{ Treatment by day (from 1 to 7 days) } & \multirow{2}{*}{$\begin{array}{l}\text { Number of } \\
\text { recovered }\end{array}$} & \multirow{2}{*}{$\begin{array}{l}\text { Percentage of } \\
\text { recovered }\end{array}$} \\
\hline & & 1 & 2 & 3 & 4 & 5 & 6 & 7 & & \\
\hline 1 & 14 & & & & & & & + & 11 & $78 \%$ \\
\hline 2 & 12 & & & & & & & + & 11 & $92 \%$ \\
\hline 3 & 15 & & & & & & & + & 14 & $93 \%$ \\
\hline 4 & 13 & & & & + & & & & 12 & $92 \%$ \\
\hline 5 & 14 & & & + & & & & & 13 & $93 \%$ \\
\hline Subtotal & & & & 68 & & & & & 61 & $89 \%$ \\
\hline
\end{tabular}

Table 9. Cows of the fourth lactation with the development $\mathrm{f}$ a pathological process corresponding to M2 lesions according to the dopfer classification

\begin{tabular}{|c|c|c|c|c|c|c|c|c|c|c|}
\hline \multirow{2}{*}{$\begin{array}{l}\text { Sample } \\
\text { number }\end{array}$} & \multirow{2}{*}{$\begin{array}{c}\text { Group of } \\
\text { animals (n) }\end{array}$} & \multicolumn{7}{|c|}{ Treatment by day (from 1 to 7 days) } & \multirow{2}{*}{$\begin{array}{l}\text { Number of } \\
\text { recovered }\end{array}$} & \multirow{2}{*}{$\begin{array}{c}\text { Percentage of } \\
\text { recovered }\end{array}$} \\
\hline & & 1 & 2 & 3 & 4 & 5 & 6 & 7 & & \\
\hline 1 & 13 & & & & & & & + & 9 & $69 \%$ \\
\hline 2 & 14 & & & & & & & + & 12 & $86 \%$ \\
\hline 3 & 12 & & & & & & & + & 10 & $83 \%$ \\
\hline 4 & 12 & & & & & + & & & 12 & $100 \%$ \\
\hline 5 & 14 & & & + & & & & & 13 & $93 \%$ \\
\hline Subtotal & & & & 65 & & & & & 56 & $86 \%$ \\
\hline
\end{tabular}

There is also a correlation between age and response time to treatment. Indicators of the effectiveness of the treatment may be considered high. The overall therapeutic effectiveness was $83 \%$ of the number of patients.

According to the table 15, sick cows of the fifth lactation succumbed to treatment slightly worse than cows of the fifth lactation, which was assumed, the therapeutic effectiveness was $83 \%$. The response to treatment occurred on day 6 for samples \# 4 and \#5. For sample \# 3, the therapeutic effectiveness was $87 \%$, and this indicator can be considered high. Indicators of samples \#1 and \#2 are also considered satisfactory, but the duration of exposure to the drug to achieve the necessary healing effect is up to one and a half weeks or more.

Treatment of cows of the first lactation with M4 lesions, which are characterized by skin changes with the use of a proliferative form (table 16). Before applying therapeutic samples, the lesion was a tightening wound surface covered with a crust. This process passes under favorable conditions to the stage of complete recovery or to a chronic relapsing form. Treatment of typical M4 stage lesions involves achieving complete asepsis of the wound surface to eliminate the risk of returning to the toxic effect of pathogenic microflora, which entails rapid regeneration of the affected tissues.

The overall therapeutic effectiveness of the treatment was $95 \%$ after the use of all 5 samples, including for the sample \#1- 87\%, \#2 - 94\%, \#3 - 93\%. For samples \# 4 and $\# 5$, the therapeutic efficacy was $100 \%$. The onset of recovery occurs on the 4th day for samples \# 1-3 and on the 3rd day-for \# 4 and \#5 (table 17).

Indicators of therapeutic effectiveness of the drug in samples \# 4 and \# 5 reached 100\%. The overall therapeutic effectiveness of treatment of second lactation cows was $96 \%$. For images \#1-3, the indicators were also high $(94,94$, and $93 \%$, respectively).

Cows of the third lactation with M4 stage lesions responded to treatment as early as 4 days after testing 1-3 samples and 3 days for 4 and 5 samples. The treatment efficiency was $94 \%$ and increased for each group according to the sample concentrations (table 18). 
Table 10. Cows of the fifth lactation with the development of a pathological process corresponding to M2 lesions according to the dopfer classification.

\begin{tabular}{|c|c|c|c|c|c|c|c|c|c|c|}
\hline \multirow{2}{*}{$\begin{array}{l}\text { Sample } \\
\text { number }\end{array}$} & \multirow{2}{*}{$\begin{array}{c}\text { Group of } \\
\text { animals (n) }\end{array}$} & \multicolumn{7}{|c|}{ Treatment by day (from 1 to 7 days) } & \multirow{2}{*}{$\begin{array}{l}\text { Number of } \\
\text { recovered }\end{array}$} & \multirow{2}{*}{$\begin{array}{l}\text { Percentage of } \\
\text { recovered }\end{array}$} \\
\hline & & 1 & 2 & 3 & 4 & 5 & 6 & 7 & & \\
\hline 1 & 11 & & & & & & & + & 8 & $73 \%$ \\
\hline 2 & 12 & & & & & & & + & 9 & $75 \%$ \\
\hline 3 & 10 & & & & & & & + & 7 & $70 \%$ \\
\hline 4 & 9 & & & & & & + & & 8 & $89 \%$ \\
\hline 5 & 10 & & & & & + & & & 9 & $90 \%$ \\
\hline Subtotal & & & & 52 & & & & & 41 & $79 \%$ \\
\hline
\end{tabular}

Table 11. Cows of the first lactation with the development of a pathological process corresponding to M3 lesions according to the

\begin{tabular}{|c|c|c|c|c|c|c|c|c|c|c|}
\hline \multirow[t]{2}{*}{ Sample number } & \multirow[t]{2}{*}{ Group of animals (n) } & \multicolumn{7}{|c|}{ Treatment by day (from 1 to 7 days) } & \multirow{2}{*}{$\begin{array}{l}\text { Number of } \\
\text { recovered }\end{array}$} & \multirow{2}{*}{$\begin{array}{l}\text { Percentage } \\
\text { of recovered }\end{array}$} \\
\hline & & 1 & 2 & 3 & 4 & 5 & 6 & 7 & & \\
\hline 1 & 16 & & & & & & & + & 12 & $75 \%$ \\
\hline 2 & 19 & & & & & & & + & 15 & $80 \%$ \\
\hline 3 & 15 & & & & & & & + & 13 & $86 \%$ \\
\hline 4 & 18 & & & & & & + & & 17 & $94 \%$ \\
\hline 5 & 15 & & & & & & + & & 15 & $100 \%$ \\
\hline Subtotal & & & 83 & & & & & & 72 & $86 \%$ \\
\hline
\end{tabular}

Table 12. Cows of the second lactation with the development of a pathological process corresponding to M3 lesions according to the dopfer classification.

\begin{tabular}{|c|c|c|c|c|c|c|c|c|c|c|}
\hline \multirow[t]{2}{*}{ Sample number } & \multirow[t]{2}{*}{ Group of animals (n) } & \multicolumn{7}{|c|}{$\begin{array}{c}\text { Treatment by day (from } 1 \text { to } 7 \\
\text { days) }\end{array}$} & \multirow[t]{2}{*}{$\begin{array}{l}\text { Number of } \\
\text { recovered }\end{array}$} & \multirow[t]{2}{*}{ Percentage of recovered } \\
\hline & & 1 & 2 & 3 & 4 & 5 & 6 & 7 & & \\
\hline 1 & 14 & & & & & & & \pm & 10 & $71 \%$ \\
\hline 2 & 16 & & & & & & & + & 13 & $81 \%$ \\
\hline 3 & 14 & & & & & & & + & 12 & $85 \%$ \\
\hline 4 & 15 & & & & & & + & & 13 & $87 \%$ \\
\hline 5 & 11 & & & & & & + & & 10 & $91 \%$ \\
\hline Subtotal & & & 70 & & & & & & 58 & $83 \%$ \\
\hline
\end{tabular}

Table 13. Cows of the third lactation with the development of a pathological process corresponding to M3 lesions according to the dopfer classification.

\begin{tabular}{|c|c|c|c|c|c|c|c|c|c|c|}
\hline \multirow{2}{*}{$\begin{array}{l}\text { Sample } \\
\text { number }\end{array}$} & \multirow[t]{2}{*}{ Group of animals (n) } & \multicolumn{7}{|c|}{ Treatment by day (from 1 to 7 days) } & \multirow[t]{2}{*}{ Number of recovered } & \multirow[t]{2}{*}{ Percentage of recovered } \\
\hline & & 1 & 2 & 3 & 4 & 5 & 6 & 7 & & \\
\hline & & & & & & & & & & \\
\hline 1 & 15 & & & & & & & $\pm^{\dagger}$ & 10 & $67 \%$ \\
\hline 2 & 13 & & & & & & & + & 11 & $85 \%$ \\
\hline 3 & 14 & & & & & & & + & 12 & $86 \%$ \\
\hline 4 & 16 & & & & & & + & & 15 & $94 \%$ \\
\hline 5 & 17 & & & & & & + & & 16 & $94 \%$ \\
\hline Subtotal & & & 75 & & & & & & 64 & $85 \%$ \\
\hline
\end{tabular}

Table 14. Cows of the fourth lactation with the development of a pathological process corresponding to M3 lesions according to the dopfer classification.

\begin{tabular}{|c|c|c|c|c|c|c|c|c|c|c|}
\hline \multirow{2}{*}{$\begin{array}{l}\text { Sample } \\
\text { number }\end{array}$} & \multirow[t]{2}{*}{ Group of animals (n) } & \multicolumn{7}{|c|}{ Treatment by day (from 1 to 7 days) } & \multirow[t]{2}{*}{ Number of recovered } & \multirow[t]{2}{*}{ Percentage of recovered } \\
\hline & & 1 & 2 & 3 & 4 & 5 & 6 & 7 & & \\
\hline 1 & 13 & & & & & & & $\pm^{*}$ & 9 & $69 \%$ \\
\hline 2 & 14 & & & & & & & $\pm^{\S}$ & 11 & $76 \%$ \\
\hline 3 & 13 & & & & & & & + & 11 & $85 \%$ \\
\hline 4 & 12 & & & & & & + & & 11 & $92 \%$ \\
\hline 5 & 16 & & & & & & + & & 11 & $93 \%$ \\
\hline Subtotal & & & 68 & & & & & & 57 & $83 \%$ \\
\hline
\end{tabular}

Cows of the fourth lactation respond to treatment, respectively, cows of the third lactation: $94 \%$ and with a response to treatment on the 4th day for 1-3 samples and on the 3rd day for 4 and 5 samples (table 19).

For cows of the fifth lactation, the overall therapeutic effectiveness was $94 \%$, but the timing of the reaction to treatment shifted and for samples 1,2 and 3 were 5 days after application of the drug. For samples 4 and 5 , the therapeutic efficacy indicators are maximum, and the recovery period is 3 days (table 20). Therefore, the use of appropriate concentrations is most appropriate. 
Table 15. Cows of the fifth lactation with the development of a pathological process corresponding to M3 lesions according to the dopfer classification.

\begin{tabular}{|c|c|c|c|c|c|c|c|c|c|c|}
\hline Sample number & Group of & \multicolumn{7}{|c|}{ Treatment by day (from 1 to 7 days) } & Number of & Percentage of \\
\hline & & 1 & 2 & 3 & 4 & 5 & 6 & 7 & & \\
\hline 1 & 14 & & & & & & & $\pm^{* *}$ & 11 & $79 \%$ \\
\hline 2 & 15 & & & & & & & $\pm^{\dagger \dagger}$ & 12 & $80 \%$ \\
\hline 3 & 15 & & & & & & & + & 12 & $87 \%$ \\
\hline 4 & 14 & & & & & & + & & 13 & $93 \%$ \\
\hline 5 & 17 & & & & & & + & & 14 & $94 \%$ \\
\hline Subtotal & \multicolumn{8}{|c|}{75} & 62 & $83 \%$ \\
\hline
\end{tabular}

Table 16. Cows of the first lactation with the development of a pathological process corresponding to M4 lesions according to the Dopfer classification.

\begin{tabular}{|c|c|c|c|c|c|c|c|c|c|c|}
\hline Sample number & Group of animals (n) & \multicolumn{7}{|c|}{ Treatment by day (from 1 to 7 days) } & Number of recovered & Percentage of recovered \\
\hline & & 1 & 2 & 3 & 4 & 5 & 6 & 7 & & \\
\hline 1 & 15 & & & & + & & & & 13 & $87 \%$ \\
\hline 2 & 16 & & & & + & & & & 15 & $94 \%$ \\
\hline 3 & 15 & & & + & & & & & 14 & $93 \%$ \\
\hline 4 & 15 & & & + & & & & & 15 & $100 \%$ \\
\hline 5 & 19 & & & + & & & & & 19 & $100 \%$ \\
\hline Subtotal & & & 80 & & & & & & 76 & $95 \%$ \\
\hline
\end{tabular}

Table 17. Cows of the second lactation with the development of a pathological process corresponding to M4 lesions according to the

\begin{tabular}{|c|c|c|c|c|c|c|c|c|c|c|}
\hline \multirow{2}{*}{ Sample number } & \multirow{2}{*}{ Group of animals (n) } & \multicolumn{7}{|c|}{ Treatment by day (from 1 to 7 days) } & \multirow{2}{*}{$\begin{array}{l}\text { Number of } \\
\text { recovered }\end{array}$} & \multirow{2}{*}{$\begin{array}{l}\text { Percentage of } \\
\text { recovered }\end{array}$} \\
\hline & & 1 & 2 & 3 & 4 & 5 & 6 & 7 & & \\
\hline 1 & 16 & & & & + & & & & 15 & $94 \%$ \\
\hline 2 & 17 & & & & + & & & & 16 & $94 \%$ \\
\hline 3 & 15 & & & + & & & & & 14 & $93 \%$ \\
\hline 4 & 16 & & & + & & & & & 16 & $100 \%$ \\
\hline 5 & 14 & & & + & & & & & 14 & $100 \%$ \\
\hline Subtotal & & & 78 & & & & & & 75 & $96 \%$ \\
\hline
\end{tabular}

Table 18. Cows of the third lactation with the development of a pathological process corresponding to M4 lesions according to the

Dopfer classification.

\begin{tabular}{|c|c|c|c|c|c|c|c|c|c|c|}
\hline Sample number & Group of & \multicolumn{7}{|c|}{ Treatment by day (from 1 to 7 days) } & \multirow{2}{*}{$\begin{array}{c}\text { Number of } \\
\text { recovered }\end{array}$} & \multirow{2}{*}{$\begin{array}{c}\text { Percentage of } \\
\text { recovered }\end{array}$} \\
\hline & & 1 & 2 & 3 & 4 & 5 & 6 & 7 & & \\
\hline 1 & 13 & & & & + & & & & 14 & $92 \%$ \\
\hline 2 & 14 & & & & + & & & & 13 & $93 \%$ \\
\hline 3 & 15 & & & & + & & & & 12 & $94 \%$ \\
\hline 4 & 12 & & & + & & & & & 11 & $92 \%$ \\
\hline 5 & 14 & & & + & & & & & 14 & $100 \%$ \\
\hline Subtotal & & & & 68 & & & & & 64 & $94 \%$ \\
\hline
\end{tabular}

Table 19. Cows of the fourth lactation with the development of a pathological process corresponding to M4 lesions according to the Dopfer classification.

\begin{tabular}{|c|c|c|c|c|c|c|c|c|c|c|}
\hline Sample number & Group of & \multicolumn{7}{|c|}{ Treatment by day (from 1 to 7 days) } & \multirow{2}{*}{$\begin{array}{l}\text { Number of } \\
\text { recovered }\end{array}$} & \multirow{2}{*}{$\begin{array}{c}\text { Percentage of } \\
\text { recovered }\end{array}$} \\
\hline & & 1 & 2 & 3 & 4 & 5 & 6 & 7 & & \\
\hline 1 & 14 & & & & + & & & & 12 & $86 \%$ \\
\hline 2 & 13 & & & & + & & & & 12 & $92 \%$ \\
\hline 3 & 11 & & & & + & & & & 10 & $91 \%$ \\
\hline 4 & 16 & & & + & & & & & 16 & $100 \%$ \\
\hline 5 & 14 & & & + & & & & & 14 & $100 \%$ \\
\hline Subtotal & & & & & & & & & 64 & $94 \%$ \\
\hline
\end{tabular}

Table 20. Cows of the fifth lactation with the development of a pathological process corresponding to M4 lesions according to the

\begin{tabular}{|c|c|c|c|c|c|c|c|c|c|c|}
\hline \multirow{2}{*}{ Sample number } & \multirow{2}{*}{$\begin{array}{c}\text { Group of } \\
\text { animals (n) }\end{array}$} & \multicolumn{7}{|c|}{ Treatment by day (from 1 to 7 days) } & \multirow{2}{*}{$\begin{array}{c}\text { Number of } \\
\text { recovered }\end{array}$} & \multirow{2}{*}{$\begin{array}{c}\text { Percentage of } \\
\text { recovered }\end{array}$} \\
\hline & & 1 & 2 & 3 & 4 & 5 & 6 & 7 & & \\
\hline 1 & 14 & & & & & + & & & 12 & $86 \%$ \\
\hline 2 & 16 & & & & & + & & & 15 & $94 \%$ \\
\hline 3 & 15 & & & & + & & & & 14 & $93 \%$ \\
\hline 4 & 13 & & & + & & & & & 13 & $100 \%$ \\
\hline 5 & 17 & & & + & & & & & 17 & $100 \%$ \\
\hline Subtotal & & & & 75 & & & & & 71 & $94 \%$ \\
\hline
\end{tabular}




\section{Conclusion}

1. The Developed drug for the treatment of diseases of the distal extremities using niosomal forms of zinc oxide and copper sulfate is presented in concentrations $0,20 \%$; $0,25 \% ; 0,30 \% ; 0,40 \% ; 1,3 \%$ and available ointment base.

All prepared samples had high stability, were easily applied to various surfaces of both the skin and its keratinized areas (hooves), and remained unchanged on the surfaces for a long time.

2. Control tests were Conducted to study the effectiveness of drug samples in concentrations $0,20 \%$; $0,25 \% ; 0,30 \% ; 0,40 \% ; 1,3 \%$ on sick cattle with various degrees of damage to the distal extremities. It was found that with the development of the intensity of the pathological process (from M1 to M4), the number of recovered animal's decreases M4 - 94.6 $\pm 2.0 \%$; M1 $94.2 \pm 3.8 \%$; M $2-86.4 \pm 11 \%$; M $3-84.0 \pm 3.0 \%$ due to the aggravation of the severity of the infectious process localized in the distal limb. The most curable were sick animals of the first and second lactation, regardless of the concentration of the samples used.

\section{References}

1. A. Gomez, N.B. Cook, J. Rieman, K.A. Dunbar, K.E. Cooley, M.T. Socha, D. Döpfer, Journal of Dairy Science, 98, 927-936 (2015)

2. Floor Biemansa, Piter Bijma, Natasja M.Bootsa Mart C.M.de Jonga, Journal Epidemics, 23, 76-84 (2018)

3. R. Cheli and C. Mortellaro 8th International Conference on Diseases of Cattle, Piacenza, Milan, Italy, 208-213 (1974)

4. I.Demirkan, L.Walker, D.Murray, W.Blowey, The Veterinary Journal, 157, 69-77 (1999)

5. Deryck H. Read, Richard L. Walker, J. Vet. Diagn. Invest., 10, pp. 67-76, (1998)

6. Schrank K, Choi BK, Grund S, Moter A, Heuner K, Nattermann H, GobelUB. Int. J. Syst. Bacteriol. 49, 43-50 (1999)

7. Evans NJ, Brown JM, Demirkan I, Singh P, Getty B, Timofte D, Vink WD, Murray RD, Blowey RW, Birtles RJ, Hart CA, Carter SD. J. Clin. Microbiol. 47, 689-696 (2009)
8. Yano T, Yamagami R, Misumi K, Kubota C, Moe KK, Hayashi T, Yoshitani K, Ohtake O, Misawa N. J. Clin. Microbiol. 47, 727-733 (2009)

9. Wilson-Welder, J. H., M. K. Elliott, R. L. Zuerner, D. O. Bayles, D. P. Alt, and T. B. Stanton. BMC Microbiol, 13, 280 (2013)

10. Gomez, A., K. S. Anklam, N. B. Cook, J. Rieman, K. A. Dunbar, K. E. Cooley, M. D. Socha, and D. Döpfer. J. Dairy Sci. 97, 4864-4875 (2014)

11. Nascimento, L. V., M. T. Mauerwerk, C. L. Dos Santos, I. R. Barros Filho, E. H. Birgel Júnior, C. S. Sotomaior, H. M. Madeira, and R. D. Ollhoff. J. Clin. Microbiol. 53, 1935-1937 (2015)

12. Evans, N. J., J. M. Brown, I. Demirkan, P. Singh, B. Getty, D. Timofte, W. D. Vink, R. D. Murray, R. W. Blowey, R. J. Birtles, C. A. Hart, and S. D. Carter. J. Clin. Microbiol. 47, 689-696 (2009b)

13. Blowey, R. W., and M. W. Sharp. Vet. Rec. 122:505508 (1988)

14. Döpfer, D., A. A. H. M. ter Huurne, J. L. Cornelisse, A. J. A. M. van Asten, A. Koopmans, F. A. Meijer, Y. H. Schukken, I. Szakall, W. Klee, and R. B. Bosma.. Vet. Rec. 140, 620-623 (1997)

15. Klitgaard, K., Boye, M., Capion, N., Jensen, T.K., J. Clin. Microbiol. 46, 3012-3020 (2008)

16. Rasmussen, M., Capion, N., Klitgaard, K., Rogdo, T., Fjeldaas, T., Boye, M., Jensen, T.K., Vet. Microbiol. 160, 151-161 (2012)

17. Döpfer, D., Anklam, K., Mikheil, D., Ladell, P., Vet. J. 193,685-693 (2012a)

18. Al-Qudah, A., Mostratos, A., Quesnel, L. J. Appl. Bacteriol. 55, 417-428 (1983)

19. Mumba, T., Kruitwagen, C., Dreher, M., Gaastra, W., van der Zeijst, B. J. Vet. Med. Ser. B 46,117-126 (1999)

20. Laven, R., Proven, M. Vet. Rec. 147, 503-506 (2000)

21. Speijers, M., Baird, L., Finney, G., McBride, J., Kilpatrick, D., Logue, D., J. Dairy Sci. 93, 57825791 (2010) 